\title{
Human Infection by Pseudoterranova decipiens (Nematoda, Anisakidae) in Chile: Report of Seven Cases
}

\author{
Rubén Mercado*, Patricio Torres/+ ${ }^{+}$Víctor Muñoz, Werner Apt*
}

Instituto de Parasitología, Universidad Austral de Chile, Casilla 567, Valdivia, Chile *Departamento de Ciencias Biomédicas, Programa de Parasitología, Universidad de Chile, Santiago, Chile

From 1997 to 1999, we identified seven human cases of infection by fourth stage larvae of Pseudoterranova decipiens in Chile. All identified larvae were coughed up by the patients. Subjects were 10-55 years old; five were female. Some patients complained of coughing, expectoration, pharyngeal pain, nausea or anal and nasal pruritus. Larvae of three patients were coughed up from $36 \mathrm{~h}$ to 7 days after having eaten raw (cebiche or sushi) or lightly fried fish. P. decipiens has a marine life cycle. Infective third stage larva develop to adult stage in pinniped mammals. The nematode eggs are voided with the host faeces and develop and hatch releasing third stage larvae. Some crustaceans and fish act as hosts of third stage larvae. Man is an accidental host for third or fourth stage larvae.

Key words: Pseudoterranova decipiens - nematode - fourth stage larvae - human infection - Chile

Anisakis simplex and Pseudoterranova decipiens are the principal species involved in human infection by nematodes of the family Anisakidae (Ishikura et al. 1993, Adams et al. 1997). This infection is frequently registered in countries where eating raw (sushi, sashimi, cebiche) or undercooked, salted or smoked fish is common (Ishikura et al. 1993). Infective third stage larvae of $P$. decipiens have been registered in Chilean species of marine fishes, and adult worms have been recovered from marine mammals (Mercado et al. 1997) as the pinnipeds Arctocephalus philippi and Otaria flavescens.

Recently, $P$. decipiens and A. simplex larvae were found in the flesh of some fresh marine fishes commercialized in the south of Chile (Torres et al. 2000), as the Chilean hake, Merluccius gayi; the tail-hake Macrouronus magellanicus; the redconger-eel, Genypterus chilensis, the flat fish, Paralichthys microps and the Chilean mackerel, Trachurus murphyi, although Chilean sanitary regulations establish that fishes for human consumption must be free of parasites.

\footnotetext{
This work was supported parcially by grant no. 199937 (Dirección de Investigación y Desarrollo, Universidad Austral de Chile).

${ }^{+}$Corresponding author. Fax: 56-63-214475. E-mail: ptorres@uach.cl

Received 31 August 2000
}

Accepted 20 December 2000
In America, human infection by anisakid nematodes has been reported in the United States (Little $\&$ Most 1973), Chile (Sapunar et al. 1976), Canada (Kowalewska-Grochowska et al. 1989), Perú (Tantalean \& Huiza 1993), and Brazil (Ishikura et al. 1993). In Chile, four cases have been reported but the parasite was recovered from only three of the patients. Two cases were produced by $P$. decipiens affecting the gastric mucosa (Mercado et al. 1997). The purpose of this short communication is to describe parasitological and clinical aspects of seven new cases of human infection by $P$. decipiens larvae in Chile.

Nematode larvae, coughed up from the throat and manually removed from the mouth by the patients, were received in the Parasitological Diagnostic Laboratory, Faculty of Medicine, Universidad de Chile, between July 1997 and November 1999. Three larvae were alive when they were examined in the laboratory. The specimens were fixed with ethanol $70 \mathrm{Gl}$ and submitted for identification. The specimens were cleared in lactophenol for morphological study. Voucher specimens were deposited in the collection of the Instituto de Parasitología, Universidad Austral de Chile (IPUAT No. 0264-0270).

The recovered larvae $(n=7)$ showed three large fleshy lips, a dorsal one with two double papillae and two subventral, each with single double papilla. Boring tooth and interlabia were absent. Excretory pore at base of subventral lips. Morphometric characteristics in $\mathrm{mm}$, included mean (range), were the following: body length 28.1 
(23.4-33.1), maximum diameter 0.8 (0.8-0.9), nerve ring 0.4 (0.4-0.5) from anterior end, oesophagus 1.9 (1.6-2.3), ventriculus $1.0(0.7-1.2)$, intestinal cecum $0.9(0.7-1.2)$, tail $0.2(0.1-0.2)$, with knoblike processes.

All larvae examined corresponded to the fourth stage of $P$. decipiens and their characteristics agree with those previously described (Mercado et al. 1997). Infective third-stage larvae can moult to the fourth inside humans (Ishii et al. 1989) as it has been described for A. simplex. In the Table data of the seven cases of infection by $P$. decipiens are summarised. Most patients were adult females. Six lived in Santiago $\left(33^{\circ} 28^{\prime} \mathrm{S}, 70^{\circ} 38^{\prime} \mathrm{W}\right)$ and the remaining in Curicó city, $201 \mathrm{~km}$ south from Santiago. Nausea and persistent pain of the pharyngeal zone were present in each of the two patient. In the last one, pain persisted for one week after the elimination of the nematode and was associated to allergic manifestation.Two larvae were coughed up by a patient but only one was recovered. Three cases mentioned the consumption of cebiche (raw fish marinated with lemon), sushi or fried fish. In these three cases larvae were coughed up between $36 \mathrm{~h}$ and 7 days after eating fish.

Several cases of infection by fourth-stage larvae of $P$. decipiens have been described in which the parasites coughed up 4 to 14 days after the patients ate raw fish meal. Some patients showed nausea, irritation of the pharynx and/or allergic symptoms, as described in the present report (Little \& Most 1973, Kates et al. 1973, Juels et al. 1975, Lichtenfelds \& Brancato 1976, Kliks 1983). Recently, a third-stage larva was reported emerging from the neck region of a North American patient after active transesophageal penetration (Amin et al. 2000). P. decipiens larvae can penetrate gastric and intestinal tissues of human patients causing clinical manifestations, but they appear to be less invasive than $A$. simplex. In some cases $P$. decipiens larvae have been found in the mouth, pharynx, larynx and oesophagus of humans, sometimes penetrating the mucosa (Ishikura et al 1993). It is probable that in the present cases larvae were in the pharyngeal or other adjacent area before moving into the patient mouth.

Most cases of human infection by anisakid worms have been described from Japan. In fact, $96 \%$ of the cases reported from different countries around the world were registered in Japan until 1990 (Ishikura et al. 1993). To prevent human infection by anisakid larvae, marine fishes must be maintained frozen under $-20^{\circ} \mathrm{C}$ for at least 7 days or cooked for a period of time long enough to raise the temperature of the innermost part of the flesh to $63^{\circ} \mathrm{C}$, for at least $15 \mathrm{sec}$ (Adams et al. 1997). The present report suggests that the number of human cases of anisakid nematodes in Chile will increases in the near future in connection with the expanding consumption of raw fish dishes.

\section{REFERENCES}

Adams AM, Murrell KD, Cross JH 1997. Parasites of risks to public health. Rev Sci Tech Off Int Epiz 16: 652-660.

Amin OM, Eidelman WS, Domke W, Bailey J, Pfeifer $\mathrm{G} 2000$. An unusual case of anisakiasis in California, U.S.A. Comp Parasitol 67: 71-75.

Ishii Y, Fujino T, Weerasooriya MV 1989. Morphology of anisakine larvae. In H Ishikura, M Namiki, (eds) Gastric Anisakiasis in Japan, Springer- Verlag, New York, p. 19-29.

Ishikura H, Kikuchi K, Nagasawa K, Ooiwa T, Takamiya H, Sato N, Sugane K 1993. Anisakidae and anisakidosis. In T Sun, Progress in Clinical Parasitology, Springer-Verlag, New York, p. 43-102.

Juels CW, Butler W, Bier JW, Jackson GJ 1975. Temporary human infection with a Phocanema sp. Am J Trop Med Hyg 24: 942-944.

Kates S, Wright KA, Wright R 1973. A case of human

TABLE

Characteristics of seven human cases of infection by Pseudoterranova decipiens

\begin{tabular}{|c|c|c|c|c|c|c|c|c|}
\hline Patient & Date & $\begin{array}{c}\text { Age } \\
\text { (years) }\end{array}$ & Sex & Origin & Symptoms & $\begin{array}{l}\text { Time from } \\
\text { ingestion of fish to } \\
\text { expulsion of larvae }\end{array}$ & $\begin{array}{l}\text { Suspected } \\
\text { source of } \\
\text { infection }\end{array}$ & $\begin{array}{l}\text { Number } \\
\text { of larvae }\end{array}$ \\
\hline 1 & 1997 & 51 & $\mathrm{~F}$ & Santiago & Coughing & - & - & 1 \\
\hline 2 & 1997 & 10 & M & Santiago & Coughing & - & - & 1 \\
\hline 3 & 1998 & 30 & $\mathrm{~F}$ & Curicó & Coughing & - & - & 1 \\
\hline 4 & 1998 & 22 & $\mathrm{~F}$ & Santiago & $\begin{array}{l}\text { Pharingeal pain } \\
\text { for one week, anal } \\
\text { and nasal pruritus, } \\
\text { expectoration }\end{array}$ & $36 \mathrm{~h}$ & $\begin{array}{l}\text { Light fried } \\
\text { Chilean hake }\end{array}$ & 1 \\
\hline 5 & 1999 & 55 & $\mathrm{~F}$ & Santiago & Coughing & 7 days & Sushi of congereel & 2 \\
\hline 6 & 1999 & 37 & M & Santiago & Nausea, coughing & 2 days & Cebiche & 1 \\
\hline 7 & 1999 & 26 & $\mathrm{~F}$ & Santiago & $\begin{array}{l}\text { Expectoration, } \\
\text { coughing }\end{array}$ & - & - & 1 \\
\hline
\end{tabular}


infection with the cod nematode Phocanema sp. Am J Trop Med Hyg 22: 606-608.

Kliks MM 1983. Anisakiasis in the Western United States: four new case reports from California. Am J Trop Med Hyg 32: 526-532.

Kowalewska-Grochowska K, Quinn J, Perry I, Sherbaniuk R 1989. A case of anisakiasis in Alberta. Can Dis Week Rep 15: 221-223.

Lichtenfels JR, Brancato FP 1976. Anisakid larva from the throat of an Alaskan eskimo. Am J Trop Med Hyg 25: 691-693.

Little MD, Most H 1973. Anisakid larva from the throat of a woman in New York. Am J Trop Med Hyg 22: 609-612.
Mercado R, Torres P, Maira J 1997. Human case of gastric infection by a fourth larval stage of Pseudoterranova decipiens (Nematoda, Anisakidae). Rev Saúde Púb 31: 131-133.

Sapunar J, Doerr E, Letonja T 1976. Anisakiasis humana en Chile. Bol Chil Parasitol 31: 79-83.

Tantalean VM, Huiza FA 1993. Nematode larvae with medical importance found in sea fish of Peruvian shore, with two records of human infections. Rev Per Med Trop UNMSM 7: 61-65.

Torres P, Moya R, Lamilla J 2000. Nematodos anisákidos de interés en salud pública en peces comercializados en Valdivia, Chile. Arch Med Vet 32: 107-113. 